\title{
BASIC POPULATION AND TAPHONOMIC ANALYSIS OF BEAR ASSEMBLAGES FROM ZA HÁJOVNOU CAVE (MORAVIA, THE CZECH REPUBLIC): A FOSSIL RECORD FROM 1987-2007
}

\author{
MARTIN SABOL \\ Department of Geology and Palaeontology, Comenius University, Mlynská dolina, SK - 84215 Bratislava, the Slovak Republic; \\ e-mail: sabol@fns.uniba.sk
}

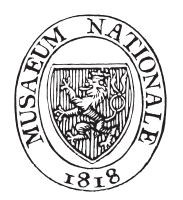

Sabol, M., (2014): Basic population and taphonomic analysis of bear assemblages from Za Hájovnou Cave (Moravia, the Czech Republic): a fossil record from 1987 - 2007. - Acta Mus. Nat. Pragae, Ser. B, Hist. Nat, 70(1-2: 91-102, Praha. ISSN 1804-6479.

Abstract. 8,210 ursid dental and osteological elements, found in fossiliferous deposits of the Moravian Za Hájovnou Cave between 1987 and 2007, were analysed from basic palaeobiological and taphonomic viewpoints. Minimally $60 \%$ of the entire ursid record is represented by Middle Pleistocene bear assemblage(-s) (Ursus ex gr. deningeri, MIS 9 to probably MIS 11), consisting of at least 21 juveniles and 16 (prime) adults. Neonates and senile adults are represented only sporadically which could indicate an assemblage(-s) with non-violent attrition. From the viewpoint of sex ratio, females predominate over males (sex index $=63.64$ ). The main cause of individual death was probably starvation during hibernation, although other reasons for perishing (disease, activity of predators, etc.) cannot be excluded. The remainder of the fossil record at the site, from late Middle Pleistocene to Late Pleistocene deposits, is probably represented by remains of cave bears ( $U$. ex gr. spelaeus).

- Ursus deningeri, Sex Ratio, Age Structure, Taphonomy, Middle Pleistocene, Za Hájovnou Cave, Moravia

Received January 20, 2014

Issued October, 2014

\section{Introduction}

Za Hájovnou Cave, situated in the Javoříčko Karst area within the Moravian territory of the Czech Republic, is one of the most important Middle Pleistocene sites in at least the Central European realm with a relatively rich fossil record of bears from the deningeri-group. Since fossil remains of these bears are not as common as finds of Late Pleistocene bears from the spelaeus-group, it is not possible to make a more detailed analysis or comparative analyses with the fossils of later bear species. In spite of this, demographic characteristics of speleoid bears as well as the modern brown bear can be considered as a good guide for the study of some aspects of Ursus deningeri palaeobiology, including timing of tooth eruption, time of birth, or composition of individual palaeopopulations from the viewpoint of sex ratio and age structure.

Within cave bear assemblages, in most cases juveniles and older adults form the largest proportion. This is considered as a clear indication of animal death during hibernation (Kurtén 1958, 1976, Stiner 1998). From the viewpoint of sex composition of adult cave bears groups, the ratios between males and females vary greatly from site to site and sometimes even among layers at one site (Weinstock 2000). This variability of sex ratio was interpreted by a change of the heredity (Abel 1929, 1931), different demands made by males and females on caves which could be used for hibernation (Kurtén 1958, 1976, Rabeder 2001, Rabeder et al. 2008, Pacher et al. 2011), or as a reflection of the diet (Stiner et al., 1998).
The preliminary results on bear assemblage(-s) from the site under study were published by Sabol (2005a, b). These showed a dominance of non-adults $(\sim 74 \%)$ and a sporadic occurrence of neonates as well as very old individuals within the studied sample as a whole. The sex ratio, based on analysis of adult canines and long bones, was determined as $56 \%: 44 \%$ (sex index $=44)$ in favour of males. These data, however, represent analysis of all in the known bear fossils at that time without regard to their original location within the cave. New finds as well as new data on the age of the fossiliferous layers in individual cave sections (Lundberg et al. 2014) allow us to specify our view on the bear assemblages from individual layers in Za Hájovnou Cave on the basis of more detailed population and taphonomic analyses of the fossil record from the various cave parts.

\section{Material and methods}

All fossil material found in the cave during field campaigns from 1987 to 2007 is stored in the Moravian Museum in Brno. In spite of the large quantity of material, fossils are often very fragmentarily preserved and only small bones (such as carpalia, tarsalia, metapodial bones, or phalanges) as well as a limited number of long bones have been found unbroken. This is caused by the process of fossilization, when teeth and bones were frequently accumulated chaotically by secondary redeposition (probably by gravitational and/or water transport?) and cemented by flowstone. 
The cave under study has a rich fossil record dominated mainly by deningeri bears from the Middle Pleistocene (Musil 2005b, Wagner 2005), although there are also fossil remains of cave bears known from Late Pleistocene deposits (Lundberg et al. 2014). Bear fossils were so far found in almost all the fossiliferous layers of the main cave areas which include: Vařekova chodba (= Vařeka's Corridor), Komín I (= Chimney I), Vykopaná chodba (= Excavated Corridor), Chodba naděje (= Corridor of Hope), and Narozeninová chodba (= Birthday Corridor).

The total number of bear fossil elements (NE) found within the individual cave parts together with the minimum number of individuals determined on the basis of dental or skeletal elements (MNIe) is presented in Tabs. 1-7. In addition the number of individual specimens (NISP), the minimum number of elements (MNE) as well as the minimum number of individuals (MNI) has also been determined. This last variable was calculated predominantly on the basis of some preserved postcranial elements (such as carpal and tarsal bones or metapodial bones) as well as teeth, which were also used for age structure determination according to the methodology used by Sabol $(2005 \mathrm{a}, \mathrm{b})$ for incisors, Debeljak (2002) for canines and Stiner $(1994,1998)$ for cheek teeth. Although these methods, based on crown wear stages and root development, show somewhat different results in the case of analysis of isolated teeth on one hand and in situ teeth on other hand, exact age determination on the basis of annual growth analysis from teeth root cross-sections was not possible within this study because of the limited amount of appropriately preserved teeth. From the viewpoint of ontogeny, two main age groups can be considered: a) non-adults, including neonates (one-year old bear cubs), juveniles ( $1-2(3)$ year old individuals $)$, and subadults ( $\sim 3-4$ year old bears); and b) adults, divided into young (prime) adults ( $>4$ year old individuals) and old (senile) adults (individuals with very heavily worn teeth, especially molars). The boundary between non-adults and adult individuals is based on mating ability. Brown bears reach sexual maturity between the third to sixth year of life, females sooner than males, although occurrences of sexual union between 2-year old animals has also been reported (Heráň 1978). Sex ratios were calculated from canines according to the methodology used by Debeljak (2004), based on the crown transversal diameter, and sex index (SI) was calculated according to Rabeder (2001). Within the text, the upper teeth are referred to by capitals (such as in "M2"), the lower ones by normal letters (such as in " $\mathrm{m} 2$ ").

\section{Results}

\section{Vařekova chodba}

The fossil record (Tab. 1) from the present entrance corridor to the site consists of cranial and postcranial remains most likely of Late Pleistocene cave bears (Ursus ex gr. spelaeus). These belonged minimally to one non-adult individual (based on the found cranial and postcranial remains) and maybe 2 to 5 adults (based on the found fragments of humeri and ulnae), although the data obtained (including also NISP $=57$ and $\mathrm{MNE}=48$ ) do not have to
Table 1. Skeletal element representation of bear remains from Vařekova chodba found during excavation campaigns between 1987-2007 at Za Hájovnou Cave (Moravia, the Czech Republic). (NE - total number of bear fossil elements found, MNIe - minimum number of individuals determined on the basis of the found dental or skeletal elements; data such as " $5 / 1$ " indicate number of right (5) and left (1) elements; this also applies to other tables).

\begin{tabular}{lc}
\hline \hline Fossil Elements (non-adults) & Vařekova chodba \\
\hline Skull fragments & $0 / 1$ \\
Humerus & $1 / 0$ \\
Femur & $1 / 0$ \\
\hline Total (NE) / MNle & $3 / 1$ \\
\hline \hline
\end{tabular}

\begin{tabular}{lc}
\hline \hline Fossil Elements (adults) & Vařekova chodba \\
\hline Skull fragments & 17 \\
Thoracic vertebrae & 1 \\
Lumbal vertebrae & 7 \\
Vertebral fragments & 3 \\
Humerus & $5 / 1$ \\
Ulna & $5 / 1$ \\
Radius & $0 / 1$ \\
Pelvis & $1 / 3$ \\
Tibia & $3 / 0$ \\
Astragalus & $0 / 1$ \\
Calcaneus & $0 / 1$ \\
Long bones fragments & 4 \\
\hline Total (NE) / MNle & $54 / 5$ \\
\hline \hline
\end{tabular}

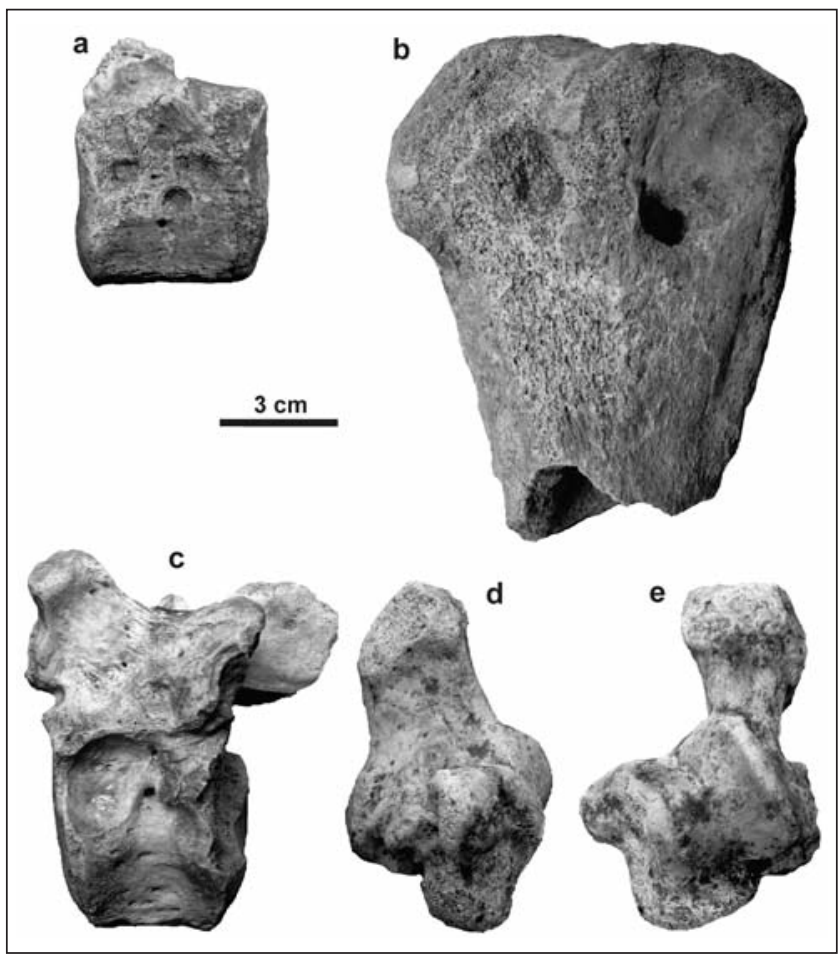

Text-fig. 1. Taphonomic and pathological phenomena of cave bear bones from Late Pleistocene deposits from Vařekova chodba in Za Hájovnou Cave (Moravia, the Czech Republic); $a$ - fragment of vertebra with bite marks; $b$ - fragment of right humerus, proximal part with bite marks; $\mathrm{c}$ - thoracic vertebra with pathological rib facet; $d-e$ - fused left astragalus with left calcaneus (d: medial view, e: dorsal view). 
represent the true picture of this bear assemblage since many fossils were placed in a heap in front of the cave during early speleological excavations. Only one third of the bones studied, predominantly pale to brown coloured, were preserved more or less without marks of taphonomic agents and pathological phenomena. The activity of predators is documented by gnawing tooth marks (Text-fig. 1) as well as irregular and V-shaped fractures. Pathological phenomena are reported on vertebrae or humeri and also recorded was a left astragalus and left calcaneus which had grown into each other (Text-fig. 1). Almost half of all the found fossils are covered by dendrites and some of these (ca. 21\%) are also covered by a thin layer of sinter. At least 8 adult bones are too robust to belong to females.

\section{Komín I (Profile ZH P-1)}

Fossils from layer 3 (loessic loam probably from the Last Glacial or its final phase only?) of the chimney filling (Tab. 2) belong also to cave bears from the spelaeus-group. So far, only 13 fossils elements (NE, NISP, MNE) have been distinguished, representing minimally remains of one juvenile and one adult individual. Whereas teeth (belonging predominantly to non-adult(-s)) are preserved more or less completely, postcranial bones (apart from an adult right astragalus) are preserved only as fragments. No pathological phenomena or marks of taphonomic agents were found.

\section{Vykopaná chodba}

From the brown loam of relict $\mathbf{A}$, only three isolated teeth and one metapodial bone (NISP $=4$ ) of minimally one adult bear were excavated (Tab. 3). Based on the transversal diameter of the worn lower canine crown $(13.4 \mathrm{~mm}$, age category V), the tooth was attributed to an adult female.

So far, only four bear teeth have been determined from Komín II (= Chimney II), belonging minimally to one non-adult individual and to one adult (Tab. 3).

Within Komín III (= Chimney III, Profile ZH P-3), fossils of bears (probably Ursus deningeri) were found in layer 3 (interglacial sediments, probably MIS 9) and layer 4 (glacial sedimentation, probably MIS 10), although there is also a relatively large quatity of bear remains but without more exact determination of their original layer position (Tab. 3). From layer 3, only one adult is so far known from the 1987-2007 collections. On the other hand, the bear assemblage from layer 4 is represented by many more fossil remains (NISP $=28, \mathrm{MNE} \sim 26$ ), belonging minimally to two juveniles (based on two fragments of two different left humeri) and two - three adult individuals. This uncertainty about MNI of adults is caused by the fossil record containing minimally one lower canine in a mandible fragment and two left upper canines of females (the crown transversal diameter of the lower canine is only $13.3 \mathrm{~mm}$ and it is $18.4 \mathrm{~mm}$ for both upper canines) as well as one fragment of os penis. The postcranial material is mostly fragmentarily preserved. The remainder of bear fossils from unknown layers in Komín III $(\mathrm{NISP}=23, \mathrm{MNE} \sim 21)$ consists of more or less fragmentary (mainly long bones) remains of minimally three individuals
Table 2. Dental and skeletal element representation of bear remains from Komín I (ZH P-1, layer 3) found during excavation campaigns between 1987-2007 at Za Hájovnou Cave (Moravia, the Czech Republic) (see also text for Tab. 1).

\begin{tabular}{lc}
\hline \hline Fossil Elements (non-adults) & $\begin{array}{c}\text { Komín 1 (ZH P-1) } \\
\text { layer 3 }\end{array}$ \\
\hline DC & 2 \\
I1 & $0 / 1$ \\
I3 & $0 / 1$ \\
M1 & $1 / 0$ \\
M2 & $0 / 1$ \\
Humerus & $1 / 0$ \\
Femur & $0 / 1$ \\
Long bones fragments & 1 \\
\hline Total (NE) / MNle & $9 / 1$ \\
\hline \hline
\end{tabular}

\begin{tabular}{lc}
\hline \hline \multicolumn{1}{c}{ Fossil Elements (adults) } & $\begin{array}{c}\text { Komín 1 (ZH P-1) } \\
\text { layer 3 }\end{array}$ \\
\hline $\mathrm{i} 2$ & $1 / 0$ \\
Thoracic vertebrae & 1 \\
Vertebral fragments & 1 \\
Astragalus & $1 / 0$ \\
\hline Total (NE) / MNle & $4 / 1$ \\
\hline \hline
\end{tabular}

(one non-adult and two adults). The determined upper right canine of $18.4 \mathrm{~mm}$ transversal crown dimension probably belonged to a prime adult female.

A small number of bear teeth and bone fragments (NISP $=9, \mathrm{MNE}=8$ ) have also been found in the brown loam of Komín IV (= Chimney IV), representing remains of minimally one juvenile animal and one adult individual. The presence of a neonate is documented by the record of one deciduous left upper canine (Tab. 3).

The main fossiliferous sequence of Vykopaná chodba is located within layers 2a, 2b, and 3 (all probably MIS 9) in Kostnice II (= Charnel-House II, Profile ZH P-5). The majority of fossils, probably belonging to Ursus deningeri individuals, were found in layer $2 \mathrm{~b}(\mathrm{NISP}=181, \mathrm{MNE} \sim 178)$. From overlying layer 2a, only 23 (= NISP, MNE $\sim 22$ ) bear remains are so far known within the 1987-2007 fossil record, attributed minimally to one neonate (a find of a deciduous upper canine), one juvenile and one adult animal (Tab. 3). Measurements of one adult left upper canine indicate a male tooth. A similar situation can be also observed in the fossil record from layer 3, from which 36 (=NISP, MNE 34) finds of deningeri bears are known, collected during the same period from 1987 to 2007 (Tab. 3). These represent fossil remains of minimally two non-adults (based on two I3 dext. and/or two m2 dext.) as well as two adults (based on two Mt IV $\sin$.). The found juvenile mandible with canine and cheek teeth (p4-m3) belonged to a female since the transversal diameter of the canine crown is only $16.8 \mathrm{~mm}$. Minimally one adult right radius shows the possibility of predator/scavenger activity, as indicated by the gnawed proximal and distal parts of this bone. The fossil record from layer $2 b$ consists of remains of minimally two neonates (based on two deciduous lower canines), six juveniles (based on six m1 dext. and/or 
Table 3. Dental and skeletal element representation of bear remains from Vykopaná chodba found during excavation campaigns between 1987-2007 at Za Hájovnou Cave (Moravia, the Czech Republic) (data in grey columns indicate the fossil record of Ursus ex gr. deningeri; see also text for Tab. 1).

\begin{tabular}{|c|c|c|c|c|c|c|c|c|c|c|c|c|c|}
\hline \multirow{3}{*}{ Fossil Elements (non-adults) } & \multirow{3}{*}{$\begin{array}{l}\text { Komin II } \\
\text { layer 2b }\end{array}$} & \multirow{2}{*}{\multicolumn{2}{|c|}{ Komin III (ZH P-3) }} & \multirow{3}{*}{$\begin{array}{c}\text { Komin IV } \\
\text { brown loam }\end{array}$} & \multirow{3}{*}{$\begin{array}{l}\text { Left side } \\
\text { non-strat. }\end{array}$} & \multicolumn{4}{|c|}{ Vykopaná chodba } & \multirow{2}{*}{\multicolumn{4}{|c|}{ Kostnice I (ZH P-6) }} \\
\hline & & & & & & & Kostnice & (ZH P-5) & & & & & \\
\hline & & layer 4 & $?$ & & & layer 2a & layer $\mathbf{2 b}$ & layer 3 & $?$ & layer $\mathbf{X}$ & $4 m$ depth & 10.5 & $?$ \\
\hline$\overline{\mathrm{DC}}$ & & $0 / 1$ & & & & 1 & 1 & & & & & & \\
\hline dc & & & & & & & 2 & & & & & & \\
\hline 11 & & & & & & & $1 / 0$ & & & & & & \\
\hline 12 & & & & & & & $0 / 1$ & $1 / 0$ & & & & & \\
\hline 13 & & & & & & $1 / 0$ & 110 & 210 & $1 / 0$ & $1 / 0$ & & & \\
\hline 13 & & & & & & $0 / 1$ & $1 / 1$ & & & & & & \\
\hline c & & & & & & & $3 / 0$ & & & & & & \\
\hline c & & & & & $1 / 1$ & $1 / 0$ & 2 & $0 / 1$ & & $1 / 0$ & & & \\
\hline Canine fragments & 1 & 5 & 1 & & & & 6 & 3 & & 1 & 1 & & \\
\hline P4 & & & & & $2 / 1$ & 0/1 & $1 / 3$ & & & $0 / 1$ & & & \\
\hline p4 & 0/1 & & & $1 / 0$ & & & $1 / 1$ & $0 / 1$ & & & & & \\
\hline M1 & & & & & $2 / 2$ & & $5 / 4$ & $1 / 0$ & & & o/1 & $1 / 0$ & \\
\hline M2 & $1 / 0$ & & & $1 / 1$ & $2 / 5$ & & $1 / 3$ & $0 / 1$ & $1 / 0$ & 0/1 & & $1 / 0$ & \\
\hline $\mathrm{m} 1$ & & $0 / 1$ & & $1 / 0$ & $0 / 1$ & $1 / 0$ & $6 / 3$ & $0 / 1$ & & & & & \\
\hline $\mathrm{m} 2$ & & $1 / 0$ & & & $1 / 3$ & $0 / 1$ & $4 / 6$ & $2 / 1+1$ & & $1 / 0$ & & $1 / 0$ & \\
\hline $\mathrm{m} 3$ & & & & $1 / 0$ & $0 / 5$ & $0 / 1$ & $4 / 1$ & $0 / 1+1$ & & $1 / 2$ & & & \\
\hline Skull fragments & & & & & 22 & & $1 / 1$ & & & & & & \\
\hline Mandibles and their fragments & & & & $1 / 0$ & $8 / 9$ & $1 / 0$ & $2 / 1+4$ & $0 / 1+1$ & & $1 / 0$ & & & \\
\hline Cervical vertebrae & & & & & 1 & & & & & & & & \\
\hline Vertebral fragments & & & & & 1 & & 1 & & & & & & \\
\hline Ribs (fragments) & & & & & 7 & & & & 1 & & & & \\
\hline Humerus & & $1 / 2$ & & & $5 / 6$ & & $0 / 4+1$ & $1 / 0$ & $4 / 0$ & & $1 / 0$ & $1 / 1$ & $0 / 1$ \\
\hline Ulna & & & o/1 & & $4 / 10$ & & $1 / 1$ & & $0 / 1$ & & & & \\
\hline Radius & & & & & 210 & & $1 / 1$ & & $0 / 1$ & 1 & & & \\
\hline $\mathrm{Mcl}$ & & & & & $1 / 1$ & & & & & & & & \\
\hline Mc III & & & & & & & & & & 0/1 & & & \\
\hline Metacarpal fragments & & & 1 & & & & & & & & & & \\
\hline Femur & & & 0/1 & & $1 / 4$ & & $2 / 0+1$ & $0 / 1$ & $0 / 1+3$ & $2 / 1+1$ & o/1 & $1 / 2$ & \\
\hline Tibia & & 0/1 & 1 & & $4 / 5$ & & $4 / 2+1$ & & 1 & 110 & & & o/1 \\
\hline Fibula & & & & & 2 & & & & & 1 & & & \\
\hline Calcaneus & & & & & $1 / 0$ & & & & & & & & \\
\hline Mt III & & & & & $0 / 1$ & & 110 & & & & & & \\
\hline Me V & & & & & $1 / 0$ & & & & $1 / 0$ & & & & \\
\hline Metapodial fragments & & & & & 2 & & 1 & & 1 & & & & \\
\hline Proximal phalanges & & & & & 1 & & & & & & & & \\
\hline Long bones fragments & & & & & 30 & & 4 & & 3 & & 1 & 4 & 1 \\
\hline Total (NE) / MNle & $3 / 1$ & $12 / 2$ & $5 / 1$ & $6 / 1$ & $165 / 10$ & $9 / 1$ & $97 / 6$ & $21 / 2$ & $19 / 4$ & $18 / 2$ & $5 / 1$ & $12 / 2$ & $3 / 1$ \\
\hline
\end{tabular}

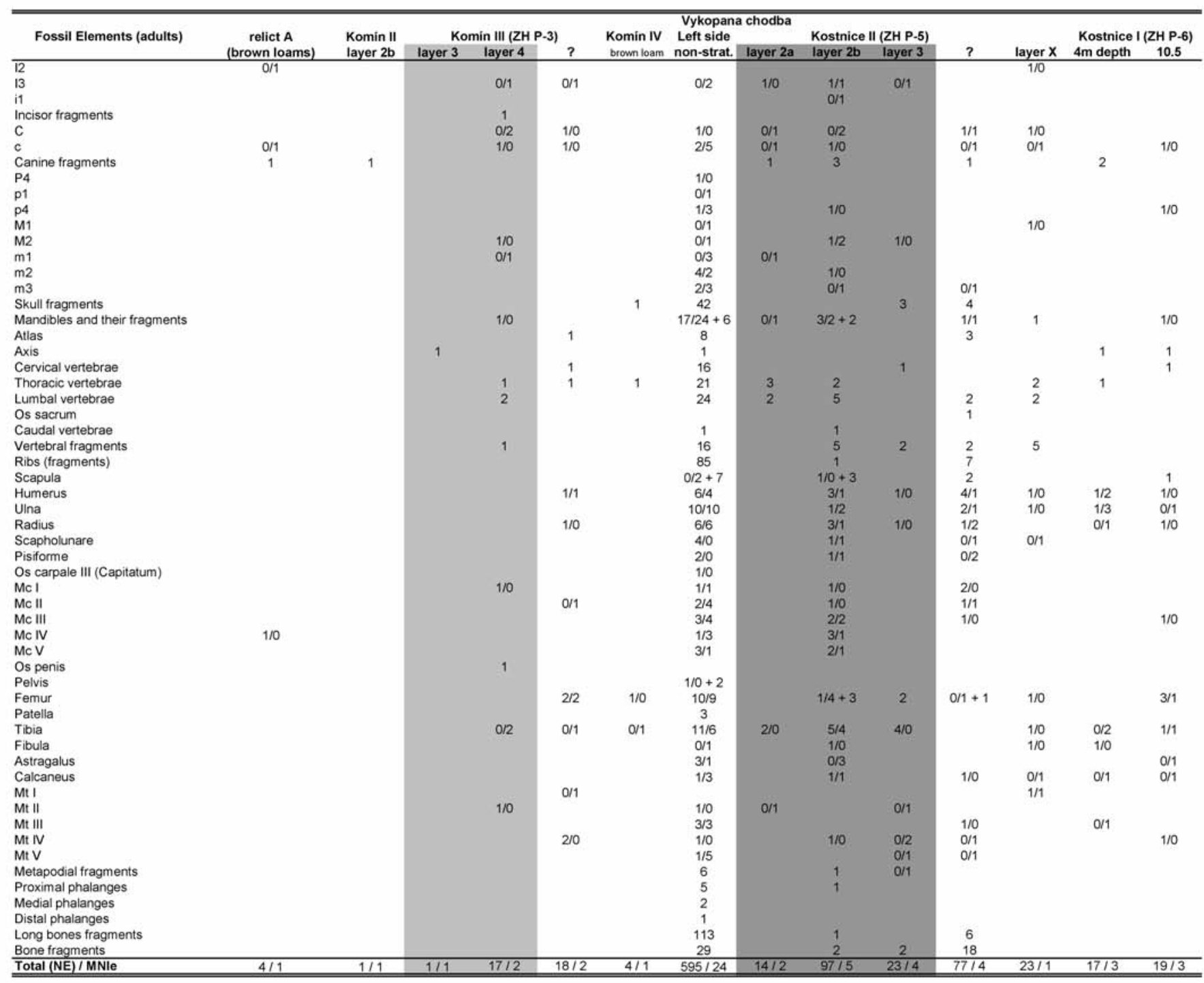


six $\mathrm{m} 2$ sin.) and two (based on two left upper canines (minimally one male) and/or two M2 sin.) to three (based on three right hemimandibles and/or three Mc IV dext. and/or three left astragali) adult individuals (Tab. 3). The exact find location of further 102 bear fossils from this cave area is unknown. Some of these $(\sim 10 \%)$, belonging minimally to 1 juvenile and 3 adults, show bite and gnaw marks.

Deposits in Kostnice I or Studna (= Charnel-House I or Well), situated close to Kostnice II, also contain bear remains. The most abundant record of bear fossils was found within layer X (NISP $=40)$, consisting of finds of minimally two non-adults and one adult individual (Tab. 3). Minimally two of the three canines found in this layer belonged to females. A small number of individuals (1 juvenile and 1-3 adults) is also known from deposits situated in "4-metre depth" (NISP $=22$ ) as well as from "layer 10.5" (a complex of brown layers, NISP = 29). A similar situation can be observed within the fossil material from undetermined layer(-s) of this cave section, consisting of 7 (NISP) bear fossils, representing remains of minimally one juvenile and one adult individual (probably a female on the basis of the crown transversal diameter of the found lower canine $=14.15 \mathrm{~mm}$ ) $($ Tab. 3 ).

The largest amount of bear fossils (NISP $=713, \mathrm{MNE}=$ 703) within the sedimentary filling of the cave section Vykopaná chodba has its origin in non-stratified layers, predominantly from the left side of this corridor (Tab. 3). The found fossils belong to minimally five non-adults (based on five $\mathrm{M} 2 \mathrm{sin}$. and/or five $\mathrm{m} 3 \mathrm{sin}$.) and five adults (based on five left lower canines) $(\mathrm{MNI}=10)$, although the fossil record of cranial and postcranial elements suggests the possibility of a larger number of individuals. Based on the most represented teeth in the sample under study ( $\mathrm{m} 2$ (or m3 resp.), $\mathrm{N}=10$ ), however, the composition of age classes is as follows: juveniles $=4$ (5) specimens, prime adults $=2$ (2) specimens, and old adults $=4$ (3) specimens. From the viewpoint of sex ratio, the crown transversal diameter of six out of eight of the lower canines is less than $18.5 \mathrm{~mm}$, probably indicates teeth of females $(\mathrm{SI}=75)$. Approximately one quarter of the mostly yellow-brown bones are damaged on the surface and/or also covered by manganese dendrites. A few of them are also covered by a thin layer of sinter. The activity of predators or scavengers (bite or gnaw marks) is documented on more than 30 bones (Text-fig. 2), supported also by the predominance of ancient (not recent) irregular fractures. In five cases, pathological phenomena (such as bone inflammation or exostosis) were also determined (Text-fig. 2).

\section{Chodba naděje}

The sedimentary filling of this cave area is documented within the profile $\mathrm{ZH} \mathrm{P}-7$, this is divided to two parts: $\mathrm{ZH}$ P-7a (layers 1-2) and ZH P-7b (layers 3-7). The bear fossils were found predominantly within layers 2, 3 (probably a Holsteinian Interglacial complex according to Musil 2005a) and 6, although a smaller quantity were also found in layers 4, 5 and 7 (Tab. 4). Ursid remains from layers 2 and 3 are preliminarily attributed to bears of the deningeri group and probably fossils from other underlying layers could also be attributed to the same taxon.

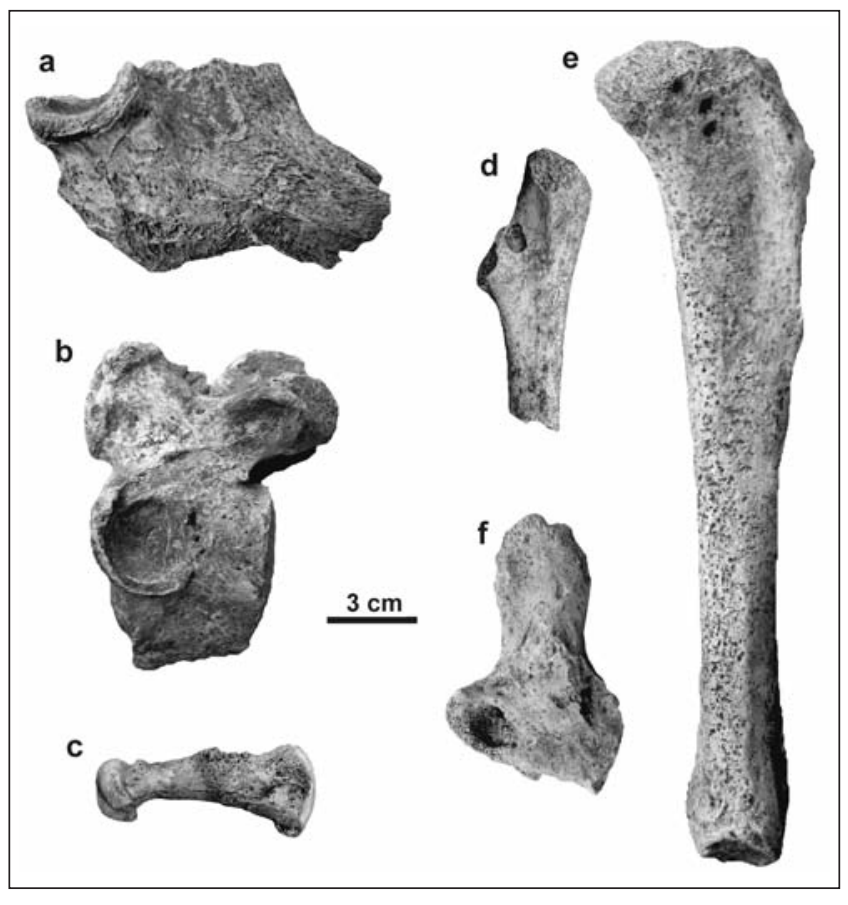

Text-fig. 2. Taphonomic and pathological phenomena of bear bones from Middle Pleistocene deposits from Vykopaná chodba in Za Hájovnou Cave (Moravia, the Czech Republic). a - fragment of left mandibula with pathological condylar process; $b$ - thoracic vertebra with pathological rib facet; $c$ Mc III dext. with exostoses; $d$ - fragment of juvenile right ulna with bite marks; e - gnawed right tibia with bite marks on proximal part; $\mathbf{f}$ - gnawed left calcaneus with bite marks.

So far, only 60 (NISP, MNE) bear fossils were studied from layer 2, representing remains of minimally one juvenile (based on one female $\mathrm{C}$ dext.) and one adult individual (based on one left hemimandible and some postcranial elements such as scapula, metacarpalia and right astragalus) (Tab. 4). On the contrary, bear remains from layer 3 are the most representative of $(\mathrm{NISP}=743, \mathrm{MNE} \sim 729)$ the whole fossil record from this cave area. Based on the wear stages of M2 dext. $(\mathrm{MNI}=12)$, six juvenile and six prime adult individuals have been distinguished. This MNI, however, is probably greater, as minimally eight non-adults (based on eight M1 dext.) and seven adults (based on seven $\mathrm{C}$ dext. and/or seven fragments of left hemimandibles and/or seven Mc IV dext.) were differentiated within the ursid fossils of this layer. From the viewpoint of sexual dimorphism, based on 14 measurable upper canines, eight females and six males could be present in the sample under study ( $\mathrm{SI}=57.14)$, although the ratio between females and males is $5: 5$ for right canines and 3 : 1 for left canines. All five measurable lower canines belonged to females. Some bear limb bones as well as some pelvis fragments show marks of predator or scavenger activity (Text-fig. 3). Exostoses have been found on the surface of one left Mc I. Most of the postcranial bones (mainly long and metapodial bones) have a thin layer of sinter on some parts and/or Mn oxides.

One neonate (based on evidence from a left humerus), one juvenile (based on $\mathrm{m} 2$ or $\mathrm{m} 3$ dext.), and two adult (based on two Mt II sin.) individuals are minimally represented in the bear fossil record from layer 4 (NISP $(\mathrm{MNE})=113)(\mathrm{Tab}$. 4). One upper right canine find belonged to an adult male. 
Table 4. Dental and skeletal element representation of bear remains from Chodba naděje (ZH P-7) found during excavation campaigns between 1987-2007 at Za Hájovnou Cave (Moravia, the Czech Republic) (data in grey columns indicate the fossil record of Ursus ex gr. deningeri; see also text for Tab. 1).
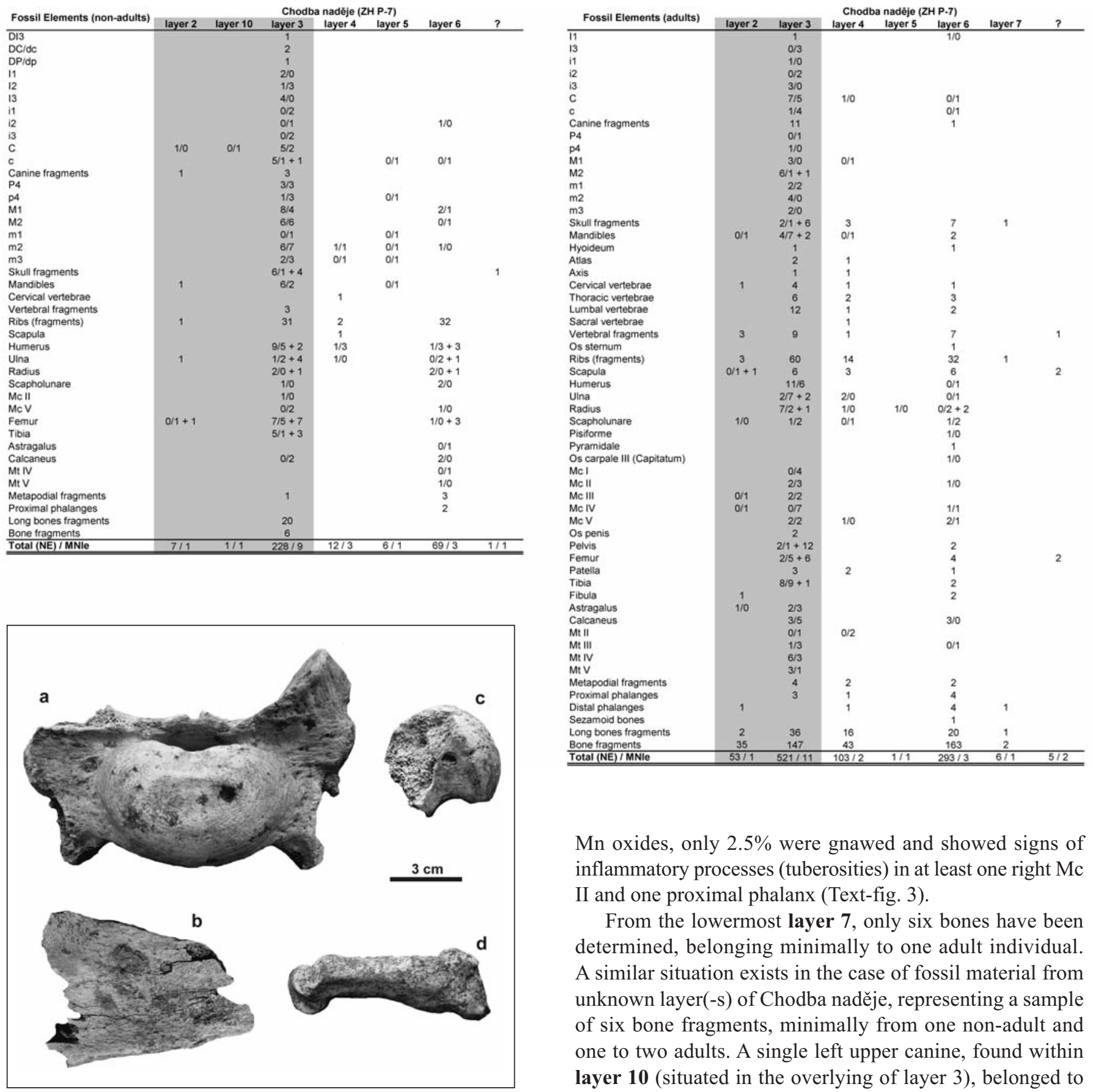

Text-fig. 3. Taphonomic and pathological phenomena of bear bones from Middle Pleistocene deposits from Chodba naděje in Za Hájovnou Cave (Moravia, the Czech Republic).

a - gnawed lumbar vertebra with a bite mark on the body head; b - fragment of pelvis with a bite mark; $c$ - femur head with a bite mark; d - Mc II dext. with a pathological phenomenon on the metapodial proximal part (tuberosity/exostosis?).

A relatively large quantity of ursid fossils are also known from layer $6(\mathrm{NISP}(\mathrm{MNE})=362)$, representing remains of minimally two juveniles (based on two M1 dext. and/or two right scapholunare and/or two right calcaneal bones) and three adults (based on three calcaneus dext.) (Tab. 4). The predominantly yellow-brown bones are mostly covered by

Mn oxides, only $2.5 \%$ were gnawed and showed signs of inflammatory processes (tuberosities) in at least one right $\mathrm{Mc}$ II and one proximal phalanx (Text-fig. 3).

From the lowermost layer 7 , only six bones have been determined, belonging minimally to one adult individual. A similar situation exists in the case of fossil material from unknown layer(-s) of Chodba naděje, representing a sample of six bone fragments, minimally from one non-adult and one to two adults. A single left upper canine, found within layer 10 (situated in the overlying of layer 3), belonged to a juvenile male.

\section{Spojovací chodba (= Connecting Passage) - Narozeninová chodba -}

Within this cave part, some sedimentary profiles were documented as containing bear fossils, discovered in several different layers. Ursid remains from Trench A (in Spojovací chodba sub-section ) were predominantly found in layers $2 \mathrm{a}$ $(\mathrm{NISP}=22, \mathrm{MNE} \sim 20, \mathrm{MNI}=2$ (minimally one juvenile and one adult individual $)$ ) and $2 \mathrm{~b}(\mathrm{NISP} / \mathrm{MNE}=42, \mathrm{MNI}=$ 6 (minimally four non-adults and two adults)) (Tabs. 5 and 6 ), which are probably correlated with layers $2 \mathrm{a}$ and $2 \mathrm{~b}$ of the profile ZH P-5 (MIS 9). A further 21 (NISP) bear fossils 
Table 5. Dental and skeletal element representation of non-adult bear remains from Spojovací chodba - Narozeninová chodba found during excavation campaigns between 1987-2007 at Za Hájovnou Cave (Moravia, the Czech Republic) (data in grey columns indicate the fossil record of Ursus ex gr. deningeri; see also text for Tab. 1).

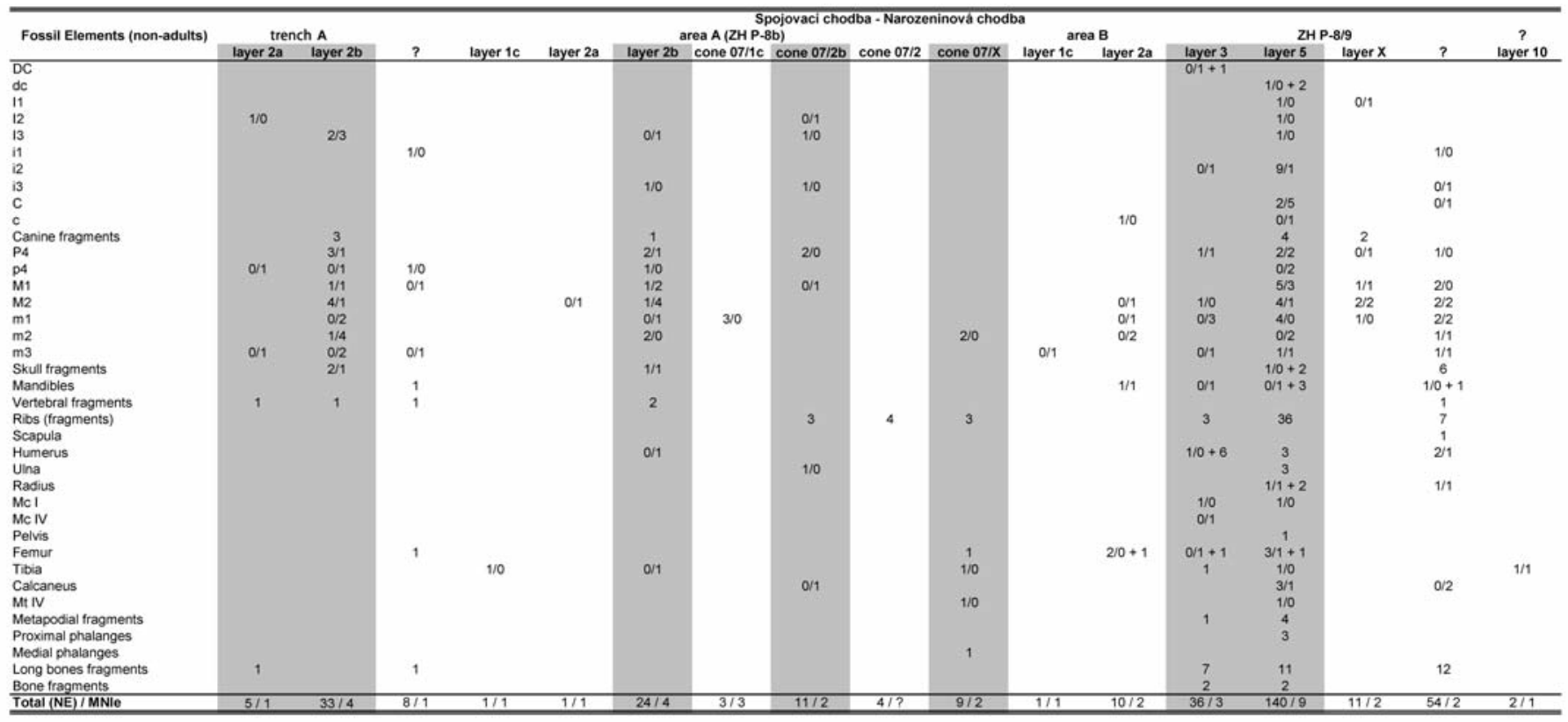

Table 6. Dental and skeletal element representation of adult bear remains from Spojovací chodba - Narozeninová chodba found during excavation campaigns between 1987-2007 at Za Hájovnou Cave (Moravia, the Czech Republic) (data in grey columns indicate the fossil record of Ursus ex gr. deningeri; see also text for Tab. 1).

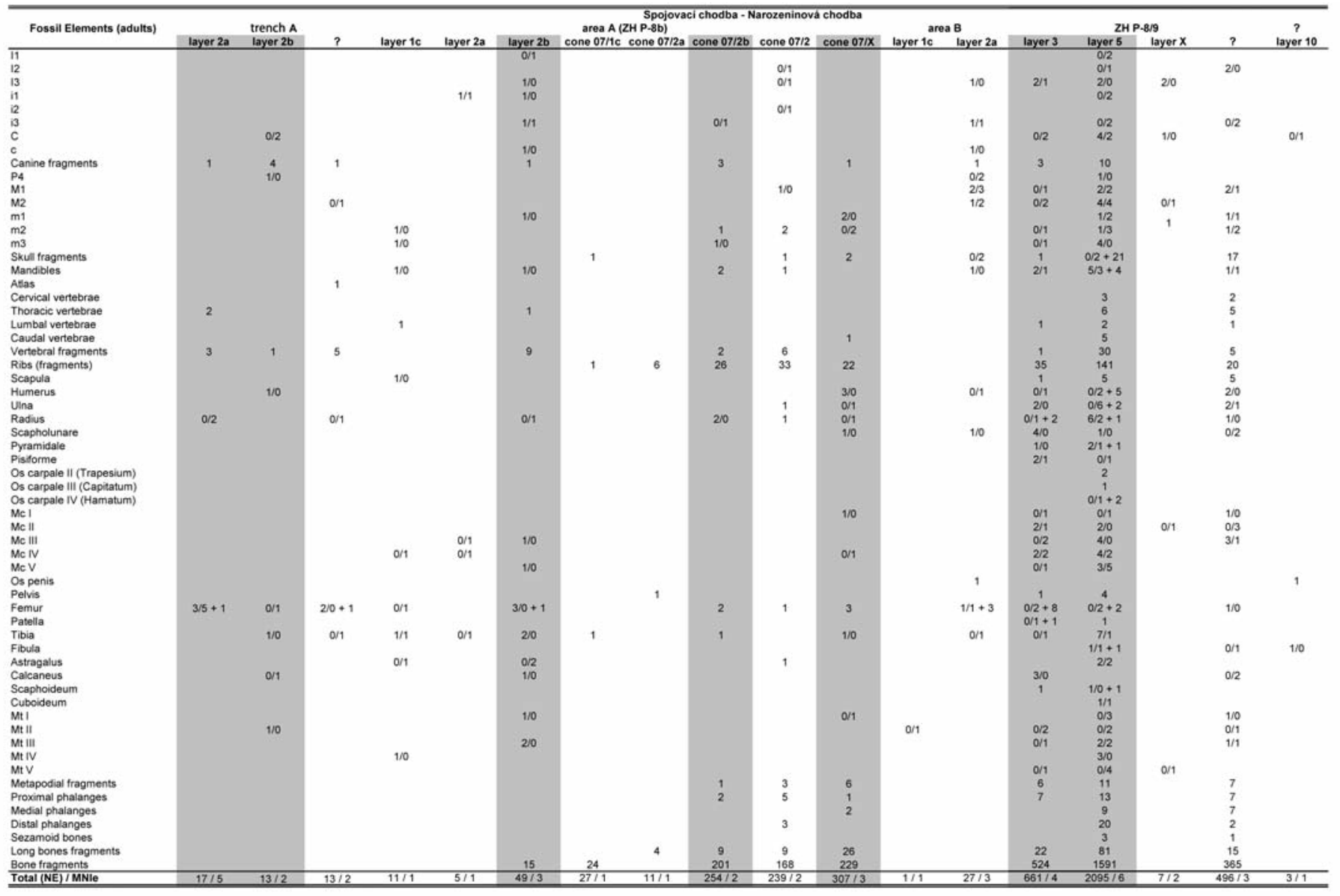

are from undetermined layer(-s) of this cave sub-section, representing remains of minimally one juvenile and one adult individual (Tabs. 5 and 6).
Fossils of bears from Area A in Narozeninová chodba (Profile ZH P-8b) were found in layers 1c, 2a, 2b, and X (including also identically labelled layers from the cone 07/2) 


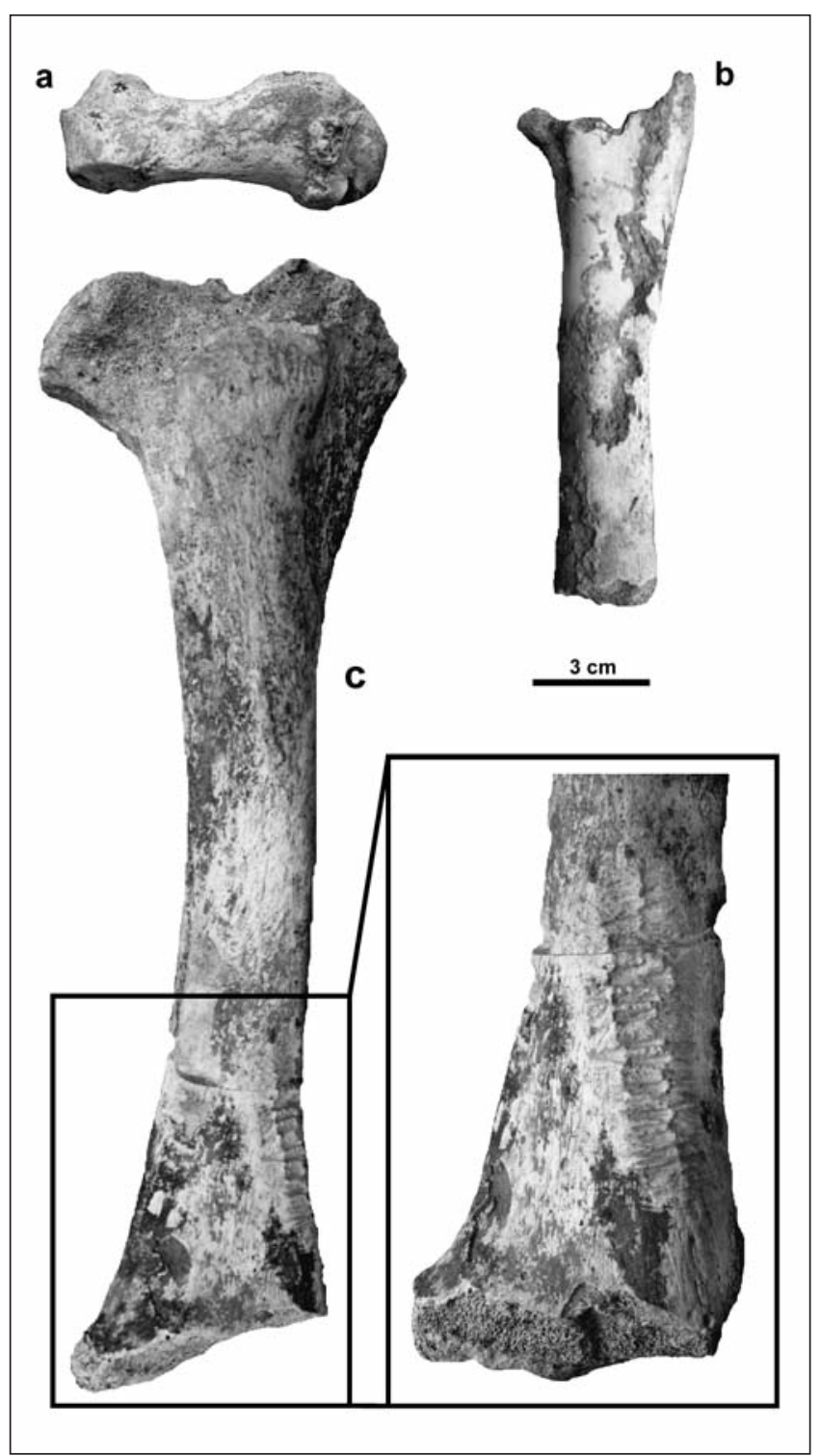

Text-fig. 4. Taphonomic and pathological phenomena of bear bones from Middle Pleistocene deposits from Spojovací chodba - Narozeninová chodba in Za Hájovnou Cave (Moravia, the Czech Republic).

a - Mc $\mathrm{V}$ sin. with a pathological phenomenon on the metapodial distal part (tuberosity/exostosis?); b - gnawed juvenile ulna; $c$ - right tibia gnawed by a large rodent (porcupine?) with detail.

(Tabs. 5 and 6). The first two layers (1c and 2a) correspond probably with layer 1 (Holocene) and 2 (Late Pleistocene?) of the profile $\mathrm{ZH} \mathrm{P}-8 / 9$ and their ursid remains (NISP $=57$, $\mathrm{MNE} \sim 56, \mathrm{MNI}=4-9$ (minimally three to five juveniles and one to four adults)) cannot be attributed to deningeri bears. On the other hand, layer $2 \mathrm{~b}$ can be correlated with layer 3 of the profile $\mathrm{ZH} \mathrm{P}-8 / 9$ and layer X with layer 4 of the same profile (both are dated to MIS 9). The fossil record from these layers is very rich, consisting of 317 bear remains from layer $2 \mathrm{~b}(\mathrm{MNI}=6-9$ (minimally four to six juveniles and two to three adults)) and 316 from layer X (MNI $=4$ (minimally two non-adults and two adults)). The exact origin of the relatively large quantity of ursid fossils (NISP $=243$ ) within the sedimentary filling of area A is, however, unknown, being labelled only as "layer 2" (Tabs. 5 and 6).
The fossil record of bears from Area B in Narozeninová chodba consists of only one juvenile (based on $\mathrm{m} 3 \mathrm{sin}$.) and one adult (based on Mt II sin.) individual from layer 1c (NISP $=2$ ) and two juveniles (based on $\mathrm{m} 2 \mathrm{sin}$.) and three adults (based on M1 sin.) from layer $2 \mathrm{a}(\mathrm{NISP}=29)$ (Tabs. 5 and 6). Both layers, preliminary dated to the Last Glacial Holocene Period, were redeposited (Musil 2005a).

The largest amount of bear fossils (NISP $=2,950, \mathrm{MNE}$ $\sim 2,938$ ) within this particular cave section (Narozeninová chodba) were found in layers 3 to 5 (MIS 9-11) of the profile ZH P-8/9. These remains are of minimally three to nine non-adults (minimally one neonate) and three to five adults (Tabs. 5 and 6). Based on the transversal diameter of the measurable left upper canine crowns, five females and only one male were distiguished $(\mathrm{SI}=83.3)$. Only ca. $2 \%$ of the found yellow to brown coloured bones are covered by $\mathrm{Mn}$ oxides. 15 bones show marks of predator/scavenger or rodent activity and pathological phenomena (such as inflammation or tuberosities) were found in minimally seven bones (Text-fig. 4). The exact origin of a further 544 ursid remains (minimally three neonates, two juveniles and three adults) from the sedimentary filling of the profile is unknown (Tabs. 5 and 6).

Two fragments of right and left juvenile tibiae, one adult left upper canine covered by sinter, a fragment of os penis as well as a fragment of adult right fibula were found in "layer 10 " of Narozeninová chodba (Tabs. 5 and 6). The exact position of this layer within individual profiles is unknown. It is not excluded that this layer corresponds with layer $\mathrm{X}$ of the profiles $\mathrm{ZH} \mathrm{P}-8 \mathrm{~b}$ or $\mathrm{ZH} \mathrm{P}-8 / 9$.

A large quantity of bear fossils were also found near a heap in front of the cave entrance $(\mathrm{NE}=956)$, belonging minimally to five non-adult (based on $\mathrm{m} 3 \mathrm{sin}$.) and six adult (based on Mc III sin.) individuals (Tab. 7). Since these ursid remains come from various layers of different cave parts, they are not included in the analysis.

\section{Ursus deningeri assemblage(-s)}

Fossils of bears from the deningeri-group were found mainly in three area of the cave site under study. These are as follows: Vykopaná chodba (Profile ZH P-3: layers 3 and 4; Profile ZH P-5: layers 2a, 2b, and 3), Chodba naděje (Profile ZH P-7: layers 2, 10, 3 and maybe others?), and Spojovací chodba - Narozeninová chodba (Trench A: layers $2 \mathrm{a}$ and $2 \mathrm{~b}$; Profile ZH P-8b: layer $2 \mathrm{~b}$ and cone $07 / 2 \mathrm{~b}$ and 07/X; Profile ZH P-8/9: layers 3 and 5). Most of these fossiliferous layers were deposited probably during the MIS 9 period, the exception being layer 4 of Profile $\mathrm{ZH} \mathrm{P-3}$ and layer 5 of Profile ZH P-8/9 which were deposited earlier, probably during the periods MIS 10 (layer 4) and MIS 11 (layer 5) (LuNDBERG et al., 2014).

In total 4,755 (NE) dental and osteological fossil elements of deningeroid bears were studied to date from the above mentioned layers, belonging minimally to 21 non-adults (based on M1 dext. and/or $\mathrm{m} 2$ sin.) and 16 adults (based on $\mathrm{C}$ sin.). Considering age cohorts present, based on 27 M2 dext. and/or $27 \mathrm{~m} 2$ sin., juvenile individuals dominated (67-78\%), mainly animals between 1-3 years old (wear class II according to Stiner 1998). 
Table 7. Dental and skeletal element representation of bear remains from the heap in front of Za Hájovnou Cave entrance (Moravia, the Czech Republic) (excavation campaigns between 1987-2007; see also text for Tab. 1).

\begin{tabular}{lc}
\hline \hline Fossil Elements (non-adults) & Halda (Heap) \\
\hline I1 & $2 / 0$ \\
I3 & $3 / 0$ \\
C & $0 / 1$ \\
C & 2 \\
Canine fragments & 5 \\
P4 & $1 / 1$ \\
M1 & $2 / 4$ \\
M2 & $4 / 3$ \\
m1 & $2 / 2$ \\
m2 & $1 / 3$ \\
m3 & $2 / 5$ \\
Skull fragments & 15 \\
Mandibles & $1 / 2+3$ \\
Axis & 1 \\
Cervical vertebrae & 1 \\
Ribs (fragments) & 9 \\
Humerus & $6 / 7+4$ \\
Ulna & 1 \\
Radius & $1 / 0+2$ \\
Femur & $2 / 2+3$ \\
Tibia & $2 / 3+2$ \\
Astragalus & $1 / 0$ \\
Calcaneus & $0 / 1$ \\
Mt III & $0 / 1$ \\
Metapodial fragments & 2 \\
Proximal phalanges & 3 \\
Long bones fragments & 16 \\
Bone fragments & 1 \\
\hline Total (NE) / MNle & $135 / 7$ \\
\hline \hline
\end{tabular}

A similar situation was also found in many other sites with a fossil record of Ursus ex gr. spelaeus, such as Zoolithenhöhle, Bärenhöhle-Höhlenstein (Weinstock 2000), Pod hradem (Gargett 1996) or Divje babe I (Debeljak 2002), as well as in some caves with an abundant fossil record of bears from the deningeri-group (e.g. Kents Cavern; McFarlane et al. 2011). Prime adults within the assemblage(-s) under study accounted for $22-30 \%$, whereas only one M2 dext. belonged to a senile adult (wear class VIII according to Stiner 1998) (Text-fig. 5). This age spectrum indicates a bear assemblage(-s) with more or less natural mortality (non-violent attrition) and the sporadic occurrence of very old individuals could be explained by the effect of disease, starvation, and/or activity of predators. Bones with bite and gnaw marks, however, most likely represent the activity of scavengers (hyenas, wolves) rather than predators (lions), although fossils of $P$. fossilis were also described from this site (Ábelová 2005, Sabol 2014). The low number of bear neonate fossils can be explained by problems with preservation of their fragile dental/osteological remains and also by their reduced

\begin{tabular}{|c|c|}
\hline Fossil Elements (adults) & Halda (Heap) \\
\hline 12 & $2 / 0$ \\
\hline 13 & $1 / 1$ \\
\hline i1 & $1 / 1$ \\
\hline C & $1 / 0$ \\
\hline c & $1 / 0$ \\
\hline Canine fragments & 10 \\
\hline p4 & $0 / 1$ \\
\hline M1 & $0 / 4$ \\
\hline $\mathrm{m} 2$ & $1 / 1$ \\
\hline Skull fragments & $1 / 0+6$ \\
\hline Mandibles & $4 / 3+3$ \\
\hline Hyoideum & 1 \\
\hline Atlas & 2 \\
\hline Axis & 2 \\
\hline Cervical vertebrae & 1 \\
\hline Thoracic vertebrae & 9 \\
\hline Lumbal vertebrae & 8 \\
\hline Vertebral fragments & 10 \\
\hline Ribs (fragments) & 38 \\
\hline Scapula & 5 \\
\hline Humerus & $8 / 3+3$ \\
\hline Ulna & $5 / 7$ \\
\hline Radius & $5 / 3+2$ \\
\hline Scapholunare & $0 / 1$ \\
\hline Pyramidale & $0 / 1$ \\
\hline Pisiforme & $3 / 0$ \\
\hline Os carpale III (Capitatum) & $0 / 1$ \\
\hline $\mathrm{McI}$ & $1 / 2$ \\
\hline Mc II & $2 / 1$ \\
\hline Mc III & $0 / 6$ \\
\hline Mc IV & $1 / 3$ \\
\hline $\mathrm{Mc} V$ & $2 / 1$ \\
\hline Os penis & 1 \\
\hline Pelvis & 1 \\
\hline Femur & $2 / 3+10$ \\
\hline Tibia & $3 / 3$ \\
\hline Fibula & $0 / 1$ \\
\hline Astragalus & $2 / 1$ \\
\hline Calcaneus & $1 / 5$ \\
\hline Mt II & $2 / 2$ \\
\hline Mt III & $1 / 2$ \\
\hline Mt IV & $0 / 1$ \\
\hline Mt V & $2 / 3$ \\
\hline Metapodial fragments & 7 \\
\hline Proximal phalanges & 9 \\
\hline Medial phalanges & 1 \\
\hline Distal phalanges & 1 \\
\hline Long bones fragments & 44 \\
\hline Bone fragments & 534 \\
\hline Total (NE) / MNle & $821 / 8$ \\
\hline
\end{tabular}




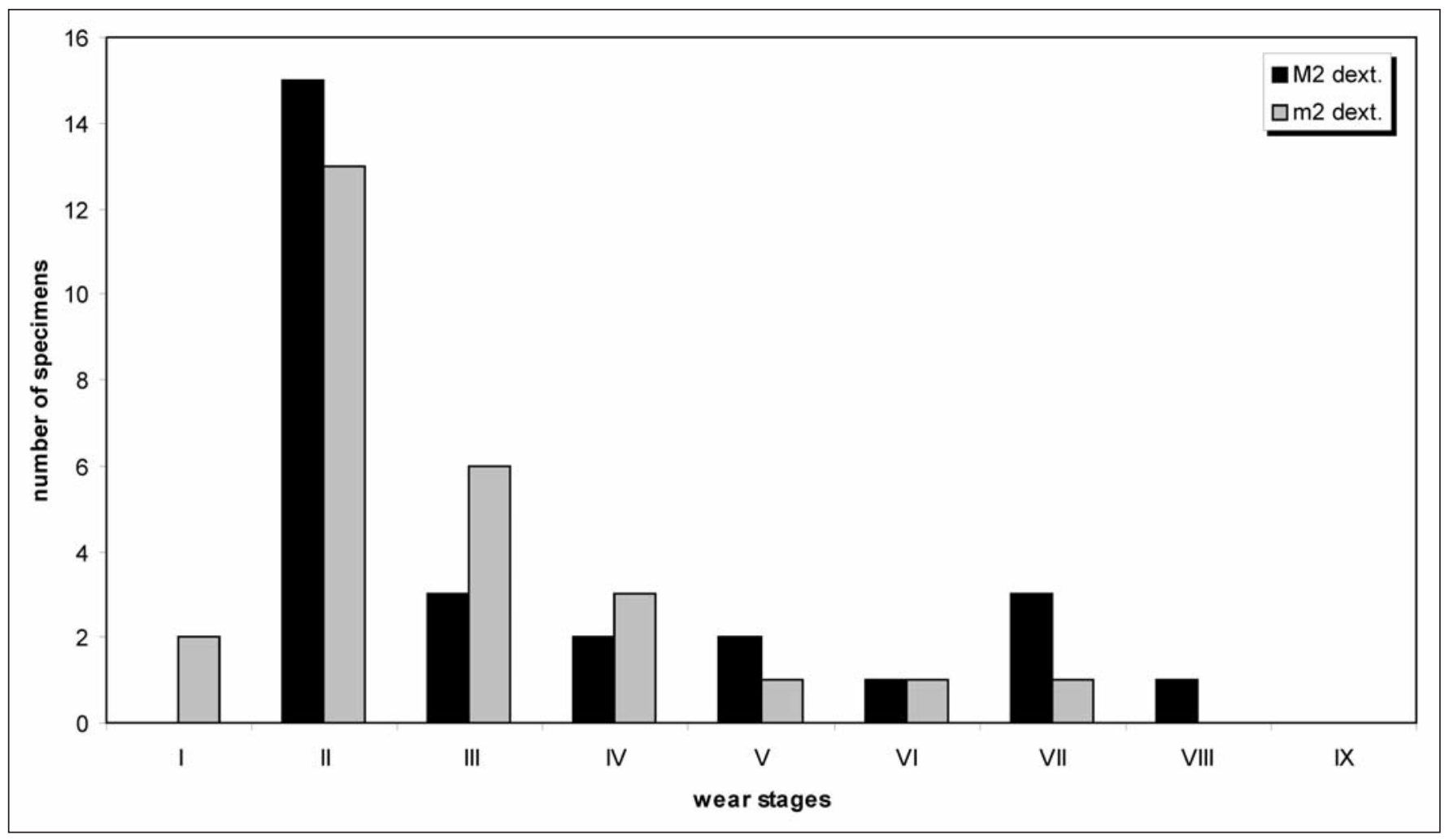

Text-fig. 5. Distribution of age classes of deningeri bears from Middle Pleistocene deposits from Za Hájovnou Cave (Moravia, the Czech Republic) based on wear stage of M2 dext. and m2 dext. (I-III: juveniles, IV-VII: prime adults, VIII-IX: senile adults; according to Stiner 1998). Juveniles distinctly outnumber adults.

resistance to transport damage. Thus, an absence of sufficient quantity of appropriate seasonal resources in connection with the influence of other stress factors, could be one of the main causes of mortality in the $U$. deningeri assemblage(-s) from Za Hájovnou Cave.

Based on the crown transversal diameter of upper canines, females predominate over males with a ratio of 7 to 5 (for right upper canines; SI $=58.3$ ) or 7 to 3 (for left upper canines, $\mathrm{SI}=70)$ with a combined sex index $=63.64$. This is in contradiction to previous data from the site which indicated a dominance of males (cf. Sabol 2005a, b). On the other hand, it clearly corresponds with data from other $U$. deningeri assemblages in European sites (e.g. from Sima de Los Huenos (García et al. 1997), Westbury (Bishop 1982), or Yarimburgaz (Stiner 1998)), where females outnumber males. A higher representation of females could be connected with the greater number of non-adults at the site, indicating useage of the cave for hibernation by pregnant females or females with cubs rather than by adult males.

Based on palaeobiological research of ursid taphocoenoses from three German caves (Barenhöhle-Höhlenstein, Sibyllenhöhle, Zoolithenhöhle), Weinstock (2000) mentioned a linear relationship between the increase in female abundance and the decrease in old individuals, assuming the possibility that females failed to achieve the old age recorded in males. A similar situation can preliminarily also be observed in the deningeri bear assemblage(-s) from Za Hájovnou Cave (minimally 7 females and minimally 1 old (senile) specimen).

\section{Conclusions}

Basic population and taphonomic analysis of more than 8,200 ursid dental and bone elements found during field campaigns between 1987-2007 in the Moravian Za Hájovnou Cave, yielded preliminary results on age structure, sex ratios as well as taphonomy of some bear assemblages. Minimally $60 \%$ of the analysed fossil remains belong to bears from the deningeri-group, probably representing Middle Pleistocene palaeopopulations (MIS 9 to MIS 11?). The rest of the so far studied ursid fossils, discovered in overlying younger deposits (late Middle to Late Pleistocene), were preliminarily attributed to cave bears (Ursus ex gr. spelaeus).

The found $U$. deningeri assemblage(-s) represent a nonviolent attrition assemblage(-s), with the dominance of non-adults (67-78\%; mainly juveniles between $1-3$ years old) and the absence (or only sporadic occurrence resp.) of neonates and senile adults. The sex ratio, based on upper canines, is approximately $60 \%: 40 \%$ (or $70 \%: 30 \%$ resp.) in favour of females $(\mathrm{SI}=63.64)$. The majority of bears died during hibernation, probably due to starvation(?), although other causes of death (disease, activity of predators, etc.) cannot be excluded.

\section{Acknowledgements}

The author would like to sincerely thank Professor Emeritus Rudolf Musil from Masaryk University in Brno for the possibility to participate in research of this site and its 
fossil record, also to Dr. Martina Roblíčková for permission to access the palaeovertebratological collections of the Moravian Land Museum - Anthropos Museum for scientific use, as well as to all friends from Moravia and Bohemia for their help. The author also gratefully acknowledges the helpful comments and suggestions made by G. Rabeder and J. Wagner. Research for this paper was carried out with financial support from the Scientific Grant Agency of the Ministry of Education of the Slovak Republic (contract under VEGA No. 1/0396/12).

\section{References}

Abel, O. (1929): Paläobiologie und Stammesgeschichte [Palaeobiology and Phyllum Phylogeny]. - Gustav Fischer, Jena, $423 \mathrm{pp}$.

Abel, O. (1931): Die Degeneration des Höhlenbären von Mixnitz und deren wahrscheinliche Ursachen [Degeneration of cave bears from Mixnitz and its probable causes]. - In: Abel, O., Kyrle, G. (eds), Die Drachenhöhle bei Mixnitz, Österreichische Staadtsdruckerei, Wien, 719-744.

Ábelová, M. (2005): Doprovodná fauna vel'kých cicavcov medvedej jaskyne „Za Hájovnou“, Javoříčsky kras [Acompanying fauna of Large Mammals in "Za Hájovnou” Cave (Javoříčko Karst, Moravia)]. - Př́rodovědné studie muzea Prostějovska, 8: 171-184. (in Slovak)

Bishop, M. (1982): The mammal fauna of the early Middle Pleistocene cavern infill site of Westbury Sub-Mendip. Somerset. - Special papers in Palaeontology, 28: 1-108.

Debeljak, I. (2002): Fossil population structure of the cave bear from the Divje babe I site, Slovenia: Preliminary results. - In: Rosendhal, W., Morgan, M., López Correa, M. (eds.), Cave-Bear-Researches/Höhlen-BärenForschungen, Abhandlung zur Karst- und Höhlenkunde, 34: 41-48.

Debeljak, I. (2004): Fossil Population Structure of the Cave Bear from Potočka zijalka (Slovenia). - In: Pacher, M., Pohar, V., Rabeder, G. (eds.), Potočka Zijalka. Palaeontological and archaeological Results of the Campaigns 1997-2000, Mitteilungen der Kommission für Quartärforschung der Österreichischen Akademie der Wissenschaften, 13: 173-182.

García, N., Arsuaga, J. L., Torres, T. (1997): The carnivore remains from the Sima de los Huesos Middle Pleistocene site (Sierra de Atapuerca, Spain). - Journal of Human Evolution, 33: 155-174.

http://dx.doi.org/10.1006/jhev.1997.0154

Gargett, R.H. (1996): Cave bears and modern human origins. The spatial taphonomy of Pod hradem Cave, Czech Republic. - University Press of America, New York, 265 pp.

Heráň, I. (1978): Zvířata celého světa. Medvědi a pandy [Animals from all over the World. Bears and Pandas]. Státní zemědělské nakladatelství, Praha, 155 pp. (in Czech)

Kurtén, B. (1958): Life and death of the Pleistocene cave bear. - Acta Zoologica Fennica, 95: 1-59.

Kurtén, B. (1976): The cave bear story. - Columbia University Press, New York, 163 pp.
Lundberg, J., Musil, R., Sabol, M. (2014): Sedimentary history of the Za Hájovnou Cave (Moravia, Czech Republic): A unique Middle Pleistocene palaeontological site. - Quaternary International, 339-340: 11-24.

http://dx.doi.org/10.1016/j.quaint.2013.04.006

McFarlane, D. A., Sabol, M., Lundberg, J. (2011): A unique population of cave bears (Carnivora: Ursidae) from the Middle Pleistocene of Kents Cavern, England, based on dental morphometrics. - Historical Biology, 23(2-3): 131-137. http://dx.doi.org/10.1080/08912963.2010.483730

Musil, M. (2005a): Jeskyně „Za Hájovnou“, výjimečná lokalita Javoříčského krasu [Za Hájovnou Cave, exceptional locality of Javoříčko Karst, Moravia]. - Přrírodovědné studie muzea Prostějovska, 8: 9-41. (in Czech)

Musil, M. (2005b): Metapodia a prstní články medvědů z jeskyně „Za Hájovnou“, Javoř́ičský kras [Metapodia and phalanges of bears from "Za Hájovnou" Cave, Javoříčko Cave System, Moravia]. - Přírodovědné studie muzea Prostějovska, 8: 143-151. (in Czech)

Pacher, M., Pohar, V., Rabeder, G. (eds.) (2011): Ajdovska Jama. Palaeontology, Zoology and Archaeology of Ajdovska jama near Krsko in Slovenia. - Mitteilungen der Kommission für Quartärforschung der Österreichischen Akademie der Wissenschaften, 20: 1-112.

Rabeder, G. (2001): Geschlechtsdimorphismus und Körpergröße bei hochalpinen Höhlenbärenfaunen. - Beiträge zur Paläontogie, 26: 117-132.

Rabeder, G., Debeljak, I., Hofreiter, M., Withalm, G. (2008): Morphological response of cave bears (Ursus spelaeus group) to high-alpine habitats. - Die Höhle, 59(1-4): 59-70.

Sabol, M. (2005a): Bear assemblage from the Za Hájovnou Cave in Moravia (Czech Republic): sex ratios and age structure. - Abhandlung der Naturhistorischen Gesellschaft Nürnberg, 45: 215-224.

Sabol, M. (2005b): Štruktúra medvedej populácie z jaskyne „Za Hájovnou“ (Morava, Česká republika) z hl'adiska zastúpenia pohlaví a vekových štádií: predbežné výsledky [A structure of bear population from Za Hájovnou Cave (Moravia, Czech Republic) from the viewpoint of sex ratios and age classes]. - Př́rodovědné studie muzea Prostějovska, 8: 153-165. (in Slovak)

Sabol, M. (2014): Panthera fossilis (ReICHenau, 1906) (Felidae, Carnivora) from Za Hájovnou Cave (Moravia, Czech Republic): A fossil record from 1987-2007. - Acta Musei Nationalis Pragae, Ser. B, Historia Naturalis, 70(1-2): 59-70.

Stiner, M. (1994): Honor among thieves: A zooarchaeological study of Neadertal ecology. - Princeton University Press, Princeton, New York, 447 pp.

Stiner, M. (1998): Mortality analysis of Pleistocene bears and its paleoanthropological relevance. - Journal of Human Evolution, 34: 303-326. http://dx.doi.org/10.1006/jhev.1997.0198

Stiner, M., Achyuthan, G., Arsebük, G., Howell, C. F., Josephson, S. C., Juell, K.E., Pigati, J., Quade, J. (1998): Recostructing cave bear paleoecology from skeletons: a cross-disciplinary study of middle Pleistocene bears from Yarimburgaz Cave, Turkey. - Paleobiology, 24: 74-98. 
Wagner, J. (2005): Morfometrická charakteristika dentálního materiálu medvědů z jeskyně „Za Hájovnou“, Javoříčský kras [Morphometric characteristic of bear dental material from “Za Hájovnou” Cave, Javoříčko Karst, Moravia]. Př́rodovědné studie muzea Prostějovska, 8: 109-142. (in Czech)
Weinstock, J. (2000): Cave Bears from Southern Germany: Sex Ratios and Age Structure. A Contribution Towards a Better Understanding of the Palaeobiology of Ursus spelaeus. - Archaeofauna, 9: 165-182. 